\title{
Adult Antiretroviral Therapy and Child Health: Evidence from Scale-up in Zambia
}

\author{
By AdRIENNE M. LuCAS AND NiCHOLAS L. WiLSON ${ }^{1}$ \\ Draft: January 14, 2013
}

\begin{abstract}
:
One in five Zambian children lives with an HIV/AIDS-infected adult. We estimate the effect that the availability of adult antiretroviral therapy (ART) has on the health of such children. Using a triple difference specification, we find that adult access to ART resulted in increased weight-forage and decreased incidence of stunting among children younger than 60 months who resided with an infected father or other infected adult in an intact household. Because the increased availability of adult ART in sub-Saharan Africa has multigenerational effects, cost-effectiveness estimates restricted to direct recipients understate the economic benefit of the treatment.
\end{abstract}

HIV/AIDS is a leading cause of mortality and morbidity in sub-Saharan Africa. In

Zambia, the location of the current study, HIV prevalence among prime aged adults was approximately 14 percent in 2007. Adult infections can have substantial negative effects on the health of children in the same household (Cluver 2011), and one in five children resided with an infected adult. Since HIV/AIDS has no cure, the centerpiece of the treatment response in lowincome countries has been to increase the availability of subsidized antiretroviral therapy (ART). With the help of substantial international support, ART now reaches almost 40 percent of eligible individuals in sub-Saharan Africa (UNAIDS 2010), benefiting infected individuals and potentially their children. Because infant and child health can have lifetime effects on human capital accumulation (e.g. Almond and Curry 2010; Lucas 2010), the ability of adult ART to improve the health of children is central to understand the cost effectiveness of ART and the future development prospects of heavily infected countries. This paper uses the expansion of subsidized adult ART availability in Zambia as a quasi-experiment to study the effect of this

\footnotetext{
${ }^{1}$ Lucas: Department of Economics, University of Delaware, 419C Purnell Hall, Newark, DE, 19716 (e-mail: alucas@udel.edu). Wilson: Department of Economics, Williams College, 24 Hopkins Hall Dr., Williamstown, MA 01267 (email: nlw3@williams.edu). We thank Sonia Bhalotra, Willa Friedman, Markus Goldstein, Isaac Mbiti, and Frank Sloan for helpful comments and suggestions. Madeleine Watson and Wentao Xiong provided superb research assistance. The NBER Africa Project provided generous financial and institutional support. This research would not be possible without the assistance of Kunyima Banda and the Network of Zambian People Living with HIV/AIDS (NZP+). All errors are our own. The findings, interpretations, and conclusions expressed in this paper are those of the authors and do not necessarily represent the views of the aforementioned individuals or the agencies who employ them.
} 
availability on the anthropometrics of children in a household with an HIV positive adult.

Prior work on large scale ART availability in sub-Saharan Africa has focused primarily on adult outcomes with no estimates of the effects of availability on directly measured child health (e.g. Bendavid et al. 2011, Baranov and Kohler 2012, Baranov et al. 2012, Friedman 2012). Based on a smaller scale intervention, Graff Zivin et al. (2009) used data from patients who sought and followed-up with ART treatment in a clinic in rural Kenya and found the initiation of ART by adults improved the anthropometrics their children.

We examine the effect of adult ART availability on the anthropometrics of children aged 0-5 years using the scale-up in Zambia as a quasi-experiment. Between 2001 and 2007, adult ART went from being virtually nonexistent in Zambia to being affordable and available at approximately 300 health facilities. We combine this expansion in treatment availability with two household surveys that contain HIV status of adult respondents in a triple difference specification -controlling for both time invariant and time varying differences between locations that did and did not receive subsidized ART, relying on the differences between households with likely HIV positive and negative adults for identification. ${ }^{2}$ We find that the local introduction of ART led to children with likely HIV positive fathers having a higher weight-for-age and a lower probability of being severely underweight. We find similar effects for children in households with likely HIV positive mothers or household heads only after we condition on households with a co-resident father. These results suggest that the availability of adult ART as is typically scaled up (without enforced treatment uptake or adherence) increases the health of children, but might not be sufficient to overcome additional hurdles faced by non-intact households. Additionally, current cost effective estimates of adult ART that ignore benefits to children are incomplete. Our

\footnotetext{
${ }^{2}$ We are not able to assign an individual's own HIV status to all individuals, instead assigning likely HIV status. See the Data section for details.
} 
results are realistic estimates of what could be expected in other scale-up programs where ART is made available, but individuals are responsible for seeking and adhering to care.

\section{Background and Setting}

Prior to 2001, almost no health facilities in Zambia offered ART, and those few that did charged prices unaffordable to the population. In 2003, the government of Zambia, with donor support, began to expand access to fully subsidized ART, first introducing it in the major urban areas and expanding access in other urban areas and rural areas along the main transportation network. By 2007, approximately 40 percent of households were within the treatment radius of an ART clinic.

The implemented ART drug regimen increases life expectancy, reduces the incidence of opportunistic infections (e.g. tuberculosis and pneumonia) that could be spread to other household members, leads to weight gain, and increases labor supply (Thirumurthy et al. 2008 and summary in the same). In the absence of treatment, an infected individual can live roughly 10 years, with a severe increase in morbidity occurring in the last 2 years of life.

\section{Conceptual Framework and Empirical Strategy}

The availability of fully subsidized adult ART could have important indirect effects on children due to the improved health of the treated adult. First, increased income or agricultural production could improve household nutrition. Second, treatment expenditures could be reallocated to nutrition. Third, treated adults would not have contagious opportunistic infections that the children could contract. Fourth, having treatment available could improve mental health in the household (Baranov et al. 2012). Our estimates are the sum of all potential effects, any of which could be differential by gender or familial relationship, on both short and longer term nutritional intake. 
The primary conceptual difficulties in estimating the effect of adult ART on children's anthropometrics are the non-random selection into treatment and the non-random expansion of ART availability. Our empirical strategy overcomes both of these obstacles. First, we are not estimating effects only for those who have sought or are adhering to treatment. Our estimates are, by design, the effect of the widespread scale-up of ART availability, averaged over those who seek, and those who do not seek treatment. Second, our triple difference specification in which we combine the typical difference-in-differences spatial and temporal variation in ART availability with a third difference of HIV status allows us to control for all differences over time between locations that did and did not receive ART, relying on differential changes in children's health due to the HIV status of household adults for identification. Therefore, we can identify the effect on children, net of the (potentially time varying) characteristics that caused one location to receive subsidized ART before another.

Formally, we combine two national household surveys, one prior to the scale-up of subsidized ART (2001) and one part way through the national scale-up (2007), with exact clinic locations and estimate

$$
\begin{aligned}
& \text { healthijt }=\alpha+\beta\left(\operatorname{HIVP}_{i j t} * A R T_{j} * \text { post }_{t}\right)+\gamma_{1} \operatorname{HIVP}_{i j t}+\gamma_{2} A R T_{j}+\gamma_{3} \text { post }_{t}+ \\
& \gamma_{4}\left(\operatorname{HIVP}_{i j t} * A R T_{j}\right)+\gamma_{5}\left(\mathrm{HIVP}_{i j t} * \text { post }_{t}\right)+\gamma_{6}\left(A R T_{j} * \text { post }_{t}\right)+X_{i j t}^{\prime} \Gamma+\eta_{\text {district }}+\varepsilon_{i j t}
\end{aligned}
$$

where health $h_{i t}$ is our anthropometric measure for child $i$ in location $j$ in year $t, H I V P$ is a dummy variable equal to one if the reference adult in the household is HIV positive, $A R T$ is a dummy variable equal to one if a subsidized ART was available within $10 \mathrm{~km}$ of the household's location prior to the household survey in 2007 (effectively an “ever ART” measure), post is a dummy variable equal to one for the households surveyed in 2007, $X^{\prime}$ includes additional individual and household level covariates (indicator variables for child's age in months, birth order, and gender; 
the reference adult's marital status, age, and years of education; month of survey and urban/rural indicators; and normalized household wealth), $\eta_{\text {dissrict }}$ are district fixed effects, and $\varepsilon_{i j t}$ is the idiosyncratic error term that allows intra- but not inter-district correlation.

$\beta$, our coefficient of interest, is the causal effect of adult ART availability on child health, capturing the incremental effect of the availability of ART on children in HIV positive households, net of effects on children in the same location at the same time who were living in HIV negative households and of effects on children who were living in HIV positive households in locations for which ART was not available prior to the 2007 household survey. The identifying assumption is that ART availability was not determined by differential trending of children's health in HIV positive versus HIV negative households. The spread of ART along transportation networks suggests this assumption is satisfied. ${ }^{3}$

\section{Data}

We combine unique data on exact clinic location and timing of ART availability from the Zambian HIV/AIDS services panel collected by Wilson (2012) with two national household level Demographic and Health Surveys (DHS) surveys collected in 2001 and 2007. The DHS data include the anthropometrics of children aged 0 to 5 ; the HIV status, education in years, and marital status of adults in the household; and the GPS coordinates of the centroid of the statistical enumeration area for each household.

Based on the geographic location of households and clinics we determine the initial date that each household was within $10 \mathrm{~km}$ of a clinic with ART service. Since the full benefits of ART to health and labor market participation occur with a delay (Thirumurthy et al. 2008), we

\footnotetext{
${ }^{3}$ Because our triple difference specification controls for time invariant and time varying characteristics of these locations, any threat to validity must simultaneously vary by geography, time, and HIV status.
} 
consider households with ART availability at least 6 months prior to the 2007 survey as ever having ART available.

Our anthropometric measures are weight-for-age z-scores and a wasting indicator to measure short-term nutritional status and height-for-age z-scores and a stunting indicator to measure longer term malnutrition. We define the z-scores using the WHO 2006 growth standards and the weight, length, and age in months in the DHS. ${ }^{4}$ As is convention, we define individuals as wasted (stunted) if their weight-(height-)for-age is more than 2 standard deviations below the reference median. The sample population exhibited substantial malnutrition in 2001 with average weight-for-age and height-for-age z-scores of -0.99 and -1.93, respectively.

As a part of the two DHS surveys, a sub-sample women aged 15-49 and men aged 15-59 were tested for HIV. Unfortunately, in the 2001 DHS only one half of surveyed households were selected to be tested and for privacy reasons HIV status cannot be directly attributed to an individual or at a geographically more refined level than a province. The 2007 DHS has substantially better coverage, and we can map HIV status to individuals as well as age groupgender-district cells. In order to maximize geographic and individual precision, we use the HIV status of tested individuals where possible and assign HIV status to the rest of the adult sample at the age group-gender-district cell level. ${ }^{5}$ Therefore, our measure of HIV status is the likely HIV status of each adult. In each specification we consider the HIV status of a single adult member of the household, the reference adult.

\footnotetext{
${ }^{4}$ We remove observations with z-scores in the top and bottom $1 \%$ of the sample to remove obvious outliers. The inclusion of these observations results in less precise, but substantively similar, estimates of our coefficients of interest. Removed individuals are included in the regressions with stunting or wasting as dependent variables.

${ }^{5}$ An alternative determination of HIV status would be to use age group-gender-district for all individuals. This method generates substantially similar results, estimated with less precision.
} 


\section{Results}

We estimate separate effects of local ART availability on children's anthropometrics

based on the likely HIV status of three different reference adults: the child's household head, mother, and father. ${ }^{6}$

TABLE 1-EFFECT OF ADULT ART ON CHILDREN'S ANTHROPOMETRICS

\begin{tabular}{|c|c|c|c|c|c|c|}
\hline & \multicolumn{6}{|c|}{ All Children with Relevant Family Member } \\
\hline & \multicolumn{3}{|c|}{ Weight For Age Z-Score } & \multicolumn{3}{|c|}{ Height for Age Z-Score } \\
\hline & $\begin{array}{l}\text { Household } \\
\text { Head } \\
(1)\end{array}$ & $\begin{array}{c}\text { Mother } \\
\text { (2) }\end{array}$ & $\begin{array}{c}\text { Father } \\
\text { (3) }\end{array}$ & $\begin{array}{l}\text { Household } \\
\text { Head } \\
\text { (4) }\end{array}$ & $\begin{array}{c}\text { Mother } \\
\text { (5) }\end{array}$ & $\begin{array}{c}\text { Father } \\
(6)\end{array}$ \\
\hline $\begin{array}{l}\text { HIV Positive X ART Ever Available } \\
\text { X Post }\end{array}$ & $\begin{array}{c}0.143 \\
(0.306)\end{array}$ & $\begin{array}{c}0.067 \\
(0.232)\end{array}$ & $\begin{array}{c}0.674 * * \\
(0.326)\end{array}$ & $\begin{array}{c}0.293 \\
(0.410)\end{array}$ & $\begin{array}{l}-0.128 \\
(0.393)\end{array}$ & $\begin{array}{c}0.083 \\
(0.438)\end{array}$ \\
\hline HIV Positive & $\begin{array}{c}0.059 \\
(0.125)\end{array}$ & $\begin{array}{c}0.062 \\
(0.149)\end{array}$ & $\begin{array}{c}0.135 \\
(0.145)\end{array}$ & $\begin{array}{c}0.151 \\
(0.194)\end{array}$ & $\begin{array}{l}-0.289 \\
(0.243)\end{array}$ & $\begin{array}{c}0.211 \\
(0.237)\end{array}$ \\
\hline ART Ever Available & $\begin{array}{c}0.046 \\
(0.080)\end{array}$ & $\begin{array}{c}0.035 \\
(0.065)\end{array}$ & $\begin{array}{c}0.087 \\
(0.082)\end{array}$ & $\begin{array}{c}0.051 \\
(0.115)\end{array}$ & $\begin{array}{c}0.023 \\
(0.099)\end{array}$ & $\begin{array}{c}0.056 \\
(0.109)\end{array}$ \\
\hline Post & $\begin{array}{c}1.084^{* * *} \\
(0.208)\end{array}$ & $\begin{array}{c}1.143^{* * *} \\
(0.209)\end{array}$ & $\begin{array}{c}1.231^{* * *} \\
(0.240)\end{array}$ & $\begin{array}{c}1.868^{* * *} \\
(0.373)\end{array}$ & $\begin{array}{c}1.787 * * * \\
(0.351)\end{array}$ & $\begin{array}{c}1.808^{* * *} \\
(0.385)\end{array}$ \\
\hline HIV Positive X ART Ever Available & $\begin{array}{l}-0.212 \\
(0.278)\end{array}$ & $\begin{array}{l}-0.146 \\
(0.217)\end{array}$ & $\begin{array}{l}-0.489 * \\
(0.293)\end{array}$ & $\begin{array}{c}-0.261 \\
(0.370)\end{array}$ & $\begin{array}{c}0.138 \\
(0.380)\end{array}$ & $\begin{array}{l}-0.104 \\
(0.375)\end{array}$ \\
\hline HIV Positive X Post & $\begin{array}{l}-0.004 \\
(0.129)\end{array}$ & $\begin{array}{l}-0.053 \\
(0.168)\end{array}$ & $\begin{array}{l}-0.215 \\
(0.148)\end{array}$ & $\begin{array}{l}-0.228 \\
(0.232)\end{array}$ & $\begin{array}{c}0.097 \\
(0.269)\end{array}$ & $\begin{array}{l}-0.243 \\
(0.278)\end{array}$ \\
\hline ART Ever Available X Post & $\begin{array}{l}-0.066 \\
(0.104)\end{array}$ & $\begin{array}{l}-0.041 \\
(0.088)\end{array}$ & $\begin{array}{l}-0.157 \\
(0.106)\end{array}$ & $\begin{array}{l}-0.102 \\
(0.158)\end{array}$ & $\begin{array}{l}-0.075 \\
(0.127)\end{array}$ & $\begin{array}{l}-0.118 \\
(0.139)\end{array}$ \\
\hline Observations & 9,755 & 10,794 & 8,000 & 9,688 & 10,728 & 7,959 \\
\hline Rsquared & 0.14 & 0.13 & 0.14 & 0.17 & 0.17 & 0.18 \\
\hline $\begin{array}{l}\text { Notes: Standard errors clustered at the } \\
\text { adult indicated at the top of the colum } \\
\text { likely HIV status for the reference hot } \\
\text { district, month of survey, urban, and f } \\
\text { reference adult is married, and norma } \\
\text { availability } 6 \text { months prior to the } 2007 \\
\text { at } 5 \% \text {; *** significant at } 1 \% \text {. }\end{array}$ & $\begin{array}{l}\text { ict level app } \\
\text { e sample is } \\
\text { ld member. } \\
\text {; age and y } \\
\text { household } \\
\text { ey. Post = } 1\end{array}$ & $\begin{array}{l}\text { in parenth } \\
\text { ited to chil } \\
\text { columns i } \\
\text { of educat } \\
\text { th. ART E } \\
\text { observati }\end{array}$ & $\begin{array}{l}\text { Each col } \\
\text { l under } 60 \\
\text { de dumm } \\
\text { of the refe } \\
\text { Available } \\
\text { from the } 2\end{array}$ & $\begin{array}{l}\text { the likely } \\
\text { old with va } \\
\text { es for age i } \\
\text { llt, a dumn } \\
\text { ouseholds } \\
\text { ey. * signi }\end{array}$ & $\begin{array}{l}\text { status of } \\
\text { anthropon } \\
\text { onths, birt } \\
\text { ariable eq } \\
\text { ocations w } \\
\text { nt at } 10 \% \text {; }\end{array}$ & $\begin{array}{l}\text { reference } \\
\text { data and } \\
\text { ler, } \\
\text { one if the } \\
\text { iRT } \\
\text { ignificant }\end{array}$ \\
\hline
\end{tabular}

In columns 1-3 of Table 1, we report results from the estimation of Equation 1 with a child's weight-for-age z-score as the dependent variable. Each column uses a different member of the household as the reference individual for adult HIV status. ${ }^{7}$ In all cases the point estimate on the triple interaction (i.e., HIV Positive X ART Ever Available X Post) is positive. This point estimate is only statistically significant for father's status, indicating that local ART availability

\footnotetext{
${ }^{6}$ The household heads are mostly the mother or father, but s/he could be any related or non-related adult. To increase the sample size, we use a broad definition of “father" that includes the child's mother's husband even though he might not be the biological father.

${ }^{7}$ Each sample is limited to individuals with the relevant reference adult in the household. Children living in households with a reference adult outside of the testing age range are not included in the column for that reference adult.
} 
increased the weight-for-age of children 0-5 in households with fathers who were likely HIV positive (column 3). ${ }^{8}$

In columns 4-6 we repeat this analysis using height-for-age as the dependent variable. In contrast to weight-for-age, a measure of short-term nutritional status, the point estimates on the triple interaction in columns 4-6 are statistically insignificant at conventional levels. As heightfor-age is a measure of longer-term nutritional status, it should be less responsive to short term changes in local ART availability. ${ }^{9}$

TABLE 2-EFFECT OF ADULT ART ON CHILDREN'S ANTHROPOMETRICS IN INTACT HOUSEHOLDS

\begin{tabular}{|c|c|c|c|c|c|}
\hline & \multicolumn{5}{|c|}{ Children with a Father in the Household } \\
\hline & \multicolumn{2}{|c|}{ Weight For Age Z Score } & \multicolumn{3}{|c|}{ Wasted } \\
\hline & $\begin{array}{l}\text { Household } \\
\text { Head } \\
(1) \\
\end{array}$ & $\begin{array}{c}\text { Mother } \\
\text { (2) }\end{array}$ & $\begin{array}{c}\text { Household } \\
\text { Head } \\
(3) \\
\end{array}$ & $\begin{array}{c}\text { Mother } \\
\text { (4) }\end{array}$ & $\begin{array}{l}\text { Father } \\
\text { (5) }\end{array}$ \\
\hline HIV Positive X ART Ever Available X Post & $\begin{array}{l}0.574^{*} \\
(0.317)\end{array}$ & $\begin{array}{l}0.478 * \\
(0.284)\end{array}$ & $\begin{array}{l}-0.172^{*} \\
(0.100)\end{array}$ & $\begin{array}{c}-0.184^{*} \\
(0.092)\end{array}$ & $\begin{array}{c}-0.220 * * \\
(0.099)\end{array}$ \\
\hline HIV Positive & $\begin{array}{c}0.172 \\
(0.135)\end{array}$ & $\begin{array}{c}0.387 * * \\
(0.167)\end{array}$ & $\begin{array}{l}-0.063 \\
(0.055)\end{array}$ & $\begin{array}{c}-0.140 * * \\
(0.058)\end{array}$ & $\begin{array}{c}-0.076 \\
(0.058)\end{array}$ \\
\hline ART Ever Available & $\begin{array}{c}0.084 \\
(0.081)\end{array}$ & $\begin{array}{c}0.095 \\
(0.075)\end{array}$ & $\begin{array}{l}-0.019 \\
(0.023)\end{array}$ & $\begin{array}{l}-0.025 \\
(0.023)\end{array}$ & $\begin{array}{l}-0.025 \\
(0.022)\end{array}$ \\
\hline Post & $\begin{array}{c}1.188^{* * *} \\
(0.239)\end{array}$ & $\begin{array}{c}1.254^{* * *} \\
(0.245)\end{array}$ & $\begin{array}{c}-0.204^{* *} \\
(0.082)\end{array}$ & $\begin{array}{c}-0.181^{* *} \\
(0.081)\end{array}$ & $\begin{array}{c}-0.217 * * \\
(0.084)\end{array}$ \\
\hline HIV Positive X ART Ever Available & $\begin{array}{l}-0.467 \\
(0.287)\end{array}$ & $\begin{array}{c}-0.501^{* *} \\
(0.245)\end{array}$ & $\begin{array}{l}0.169 * \\
(0.092)\end{array}$ & $\begin{array}{c}0.183^{* *} \\
(0.089)\end{array}$ & $\begin{array}{c}0.201^{* *} \\
(0.090)\end{array}$ \\
\hline HIV Positive X Post & $\begin{array}{l}-0.155 \\
(0.137)\end{array}$ & $\begin{array}{l}-0.317 \\
(0.202)\end{array}$ & $\begin{array}{c}0.067 \\
(0.053)\end{array}$ & $\begin{array}{c}0.144 * * \\
(0.062)\end{array}$ & $\begin{array}{c}0.092 \\
(0.056)\end{array}$ \\
\hline ART Ever Available X Post & $\begin{array}{l}-0.137 \\
(0.105)\end{array}$ & $\begin{array}{l}-0.121 \\
(0.096)\end{array}$ & $\begin{array}{c}0.034 \\
(0.030)\end{array}$ & $\begin{array}{c}0.034 \\
(0.028)\end{array}$ & $\begin{array}{c}0.045 \\
(0.030)\end{array}$ \\
\hline Observations & 7,911 & 8,205 & 8,299 & 8,614 & 8,398 \\
\hline Rsquared & 0.14 & 0.14 & 0.06 & 0.06 & 0.06 \\
\hline
\end{tabular}

In Table 1 the sample varied with the presence of a reference adult in the household. Therefore, the differential findings by reference adult could be driven by sample selection or

\footnotetext{
${ }^{8}$ In Table 1, we also find a strong statistical relationship between "Post" and improved nutritional status, reflecting the nationwide improvement in living standards between 2001 and 2007. We do not find a statistically significant coefficient on "ART Ever Available" despite the nonrandom scale-up of ART availability, indicating that, conditional on district and urban/rural fixed effects and other controls, children had the same average anthropometrics in 2001 regardless of whether ART would become available prior to 2007.

${ }^{9}$ Only half our sample was within the treatment radius more than 2 years prior to the 2007 survey with about $25 \%$ first within a radius 6-12 months prior to the survey. Given potential enrollment, access, and informational delays, a lack of an effect for height is not surprising and serves as a placebo test.
} 
differential effects of ART availability. Columns 1 and 2 of Table 2 repeat Table 1 using the restricted sample of children who resided with their fathers and the reference adult, a sample analogous to column 3 of Table 1. Conditional on the father residing in the household, local ART availability appears to increase child weight-for-age when either mothers or household heads are likely in need of the available treatment. ${ }^{10}$ Similar to the results presented using the full sample, local ART availability does not affect height-for-age (results not presented). The differential effects by household structure suggest that the impact of local ART availability on child health might be mediated by either household structure or the familial relationship of the child to the infected adult.

To test for the effect of ART availability on extreme malnutrition, columns 3 to 5 of Table 2 use a linear probability model to examine the effects of local ART availability on the likelihood of wasting over the sample of children with resident fathers. We find that local ART availability reduced the likelihood of extreme malnutrition for children living with a coresidential father and an adult who was likely infected with HIV. ${ }^{11}$

\section{Discussion and Conclusion}

HIV/AIDS has the potential to devastate the health of infected adults and their affected children. Despite the importance of children as the future drivers of economic development and the centrality of antiretroviral therapy (ART) as the current treatment response, the evidence on the effects of ART provision at-scale on the affected children is scant. We examine the effects of the Zambia national ART program on the anthropometrics of children age 0-5 living in households with infected adults. Our estimates suggest that local ART availability increased weight-for-age, a measure of short-term nutritional status, of children in likely HIV positive

\footnotetext{
${ }^{10}$ The HIV status of fathers and other household adults are positively, but not perfectly correlated. Therefore, these estimates could be further evidence of the importance of paternal treatment.

${ }^{11}$ In results not presented, we do not find an effect of likely HIV status on stunting.
} 
households in which a father was present. Further research will explore the potential mechanisms behind this finding. ${ }^{12}$

\section{REFERENCES}

Baranov, Victoria and Hans-Peter Kohler. 2012. “The Impact of AIDS Treatment on Savings and Human Capital Investment in Malawi,” unpublished.

Baranov, Victoria, Daniel Bennett, and Hans-Peter Kohler. 2012. “The Indirect Impacts of Antiretroviral Therapy,” unpublished.

Bendavid, E., C. Holmes, J. Bhattacharya, and G. Miller. 2012. "HIV development assistance and adult mortality in Africa,” Journal of the American Medical Association, 307(19): 2060-2067.

Almond, Doug and Janet Currie. 2011. “Human Capital Development Before Age Five.” In Orley Ashenfelter and David Card (eds.) Handbook of Labor Economics, Volume 4b., Chapter 15, 1315-1486.

Cluver, Lucie. 2011. “Children of the AIDS pandemic.” Nature, 474: 27-29.

Friedman, Willa. 2012. “Antiretroviral Access and Behavior Change,” unpublished.

Graff Zivin, Joshua, Harsha Thirumurthy, and Markus Goldstein. 2009. “AIDS treatment and intrahousehold resource allocation: Children’s nutrition and schooling in Kenya.” Journal of Public Economics, 93: 1008-15.

Lucas, Adrienne M. “Malaria Eradication and Educational Attainment: Evidence from Paraguay and Sri Lanka,” American Economic Journal: Applied Economics, 2(2): 46-71.

Thirumurthy, Harsha, Joshua Graff Zivin, and Markus Goldstein. 2008. “The Economic Impact of AIDS Treatment: Labor Supply in Western Kenya,” Journal of Human Resources,

\footnotetext{
${ }^{12}$ Potential mechanisms include differential adherence, uptake, or labor market returns to health or that the availability of ART might result in an effect too small to detect or insufficient to overcome any health deficit in households of single, infected mothers whose husbands likely died of AIDS.
} 
43(3): 511-552.

Wilson, Nicholas L.. 2012. "Fertility responses to prevention of mother-to-child transmission of HIV,” unpublished.

UNAIDS. 2010. 2010 Report on the Global AIDS Epidemic. United Nations Programme on HIV/AIDS (UNAIDS). Geneva, Switzerland. 